\title{
Stakeholder Value Creation: Comparing ESG and Value Added in European Companies
}

\author{
Silvana Signori ${ }^{1, *(\mathbb{D})}$, Leire San-Jose ${ }^{2, *(\mathbb{D}}$, Jose Luis Retolaza ${ }^{3}(\mathbb{D})$ and Gianfranco Rusconi ${ }^{4}$ \\ 1 Department of Management, University of Bergamo, 24127 Bergamo, Italy \\ 2 Financial Economic II Department, University of the Basque Country, UPV/EHU, 48015 Bilbao, Spain \\ 3 Deusto Business School, University of Deusto, 48014 Bilbao, Spain; joseluis.retolaza@deusto.es \\ 4 Department of Law, University of Bergamo, 24127 Bergamo, Italy; gianfranco.rusconi@unibg.it \\ * Correspondence: silvana.signori@unibg.it (S.S.); leire.sanjose@ehu.eus (L.S.-J.)
}

Citation: Signori, S.; San-Jose, L.;

Retolaza, J.L.; Rusconi, G. Stakeholder

Value Creation: Comparing ESG and

Value Added in European Companies. Sustainability 2021, 13, 1392.

https://doi.org/10.3390/

su13031392

Academic Editors: Marc A. Rosen, Maria Serena Chiucchi, Mara Del Baldo and Paola Demartini Received: 27 November 2020

Accepted: 26 January 2021

Published: 29 January 2021

Publisher's Note: MDPI stays neutral with regard to jurisdictional claims in published maps and institutional affiliations.

Copyright: (c) 2021 by the authors. Licensee MDPI, Basel, Switzerland. This article is an open access article distributed under the terms and conditions of the Creative Commons Attribution (CC BY) license (https:// creativecommons.org/licenses/by/ $4.0 /)$.

\begin{abstract}
In recent years, a renewed interest in value creation for stakeholders has been witnessed in different contexts. Different tools have been proposed to try to grasp and measure such value(s) but, in many cases, the main perspective remains that of the shareholders. To contribute to the field of research that aims to discuss novel ways of thinking about value creation measurement, this paper addresses the relationship between ESG (Environmental, Social, and Governance) ratings and Value Added, as proxies of value creation and distribution for stakeholders. In particular, we consider whether ESG ratings are able to capture companies that are characterized by their capacity for generating higher Value Added for stakeholders. Our analysis uses the frontier methodology combined with means comparison. Data from 2018 were downloaded from EIKON, for all companies within the Euro zone and for all sectors (1932 companies, of which 399 held an ESG rating, compared with 1533 without ESG analysis). Our analysis reveals that, although ESG is theoretically considered a good social responsibility proxy, ESG indices cannot be used as an indicator of value creation for stakeholders but, rather, must be considered as only one of the components. This implies a need to review the limitations of ESG ratings and establish that the relevant indices are not suitable for use in universal or absolute decision-making.
\end{abstract}

Keywords: stakeholders value; value creation; value distribution; value added; ESG

\section{Introduction}

On 19 August 2019, a group of CEOs from large companies in the U.S. signed a new Statement on the Purpose of the Corporation, in which they maintained that the purpose of a corporation is no longer "only" maximizing the returns of shareholders but, rather, to serve the interests of all of their stakeholders [1]. This new step has been welcomed as a clear and strong signal that "the tide has shifted, replacing shareholder primacy with a multistakeholder purpose for corporations" [2] (p. 1225).

Corporate stakeholder management initially arose and developed almost exclusively in the sphere of managerial studies [3]. Whilst early publications implicitly proposed a normative approach to stakeholders (see, e.g., [4,5]), it was not long before the explicit adoption of stakeholder thinking in the business ethics literature appeared. In any case, keynote papers regarding stakeholder business ethics (see [6-11]) focused more on ethics in managerial and organizational contexts than on valuation, accounting, and accountability. Therefore, it is not surprising that only in recent years have scholars become increasingly interested in issues such as "stakeholder value" and "value creation for stakeholders" [12-15]. Furthermore, although the stakeholder approach has been consistently considered 'responsible behavior', its connection with value creation and distribution is sometimes taken for granted. Indeed, scant attention has been paid to these questions in recent years [16].

In fact, stakeholder theory represents an interesting practical perspective from which to investigate the complex socio-economic environments that businesses operate under; 
however, the business rhetoric in recent years has favored an emphasis on shareholder wealth creation. For example, despite numerous studies investigating the economic effects of good stakeholder management, the emphasis was mostly strictly given to financial performance and shareholder benefits (see, e.g., [17-20]). Undeniably, as Rönnegard and Smith [21] concluded, "shareholder wealth maximization has become so entrenched in managerial thinking that it rises to the level of a norm that continues to organize corporate activity and managerial decision making" [2] (p. 1227). Any shift toward the broader stakeholder-oriented purpose of corporations needs to be supported by a cultural shift, that is, a new way of thinking and looking at companies.

In response to the invitation to share new narratives and to discuss the different ways that value creation for stakeholders could be measured $[2,16]$, this paper presents and discusses the relationships between two possible means of assessing value creation for stakeholders: ESG (Environmental, Social, and Governance) ratings and Economic Value Added.

ESG ratings have been increasingly used, mainly by investors, to valuate and select companies based on how companies treat their stakeholders, as well as the environment they can affect and how they manage their corporate governance. ESG ratings may, therefore, be considered as a good "proxy" of social [22] and/or stakeholder responsibility [23]. However, ESG ratings are mainly based on qualitative information and are not specifically focused on the processes of value creation and distribution to stakeholders [24] and for this reason, we incorporated the concept of Economic Value Added into our analysis. Recent studies have underlined how economic inequalities around the world are the result of unfair value distribution processes and the appropriation of wealth by some stakeholders at the expenses to others $[16,25]$. Furthermore, given that ESG ratings have become increasingly used by different actors-in particular, investors-to evaluate and make decisions, the specific objective of this paper is to consider whether ESG ratings are capable of capturing companies with higher value creation for stakeholders. If this is true, ESG could be considered a good proxy of value creation and distribution for stakeholders.

With this study, we aim to fill different gaps, both in the literature and in practice. First of all, there exists an increasing need for further studies investigating the intriguing topic of value creation for stakeholders in particular, from an accounting perspective. Then, ESG ratings are prevalently investigated in relation to financial performance as a way to measure their capability to create value for shareholders. A more holistic view of the use of ESG ratings as a tool to represent both value creation and distribution is still lacking in the literature. Specifically, to the best of our knowledge, no studies have been carried out to uncover the links between ESG ratings and Value Added.

For our research, we analyzed data from Thomson Reuters EikonTM for all companies included in the Euro zone and for all sectors (with the exception of Healthcare and Financial Services). The sample comprised 1932 companies, 399 of which held an ESG rating (1532 were without ESG data). An analysis was conducted using 2018 data, following the return to 'normality' of the European market and before the Covid-19-related crisis, in order to offset the impact of the crisis on the results obtained. Six different hypotheses were formulated in order to investigate the relationships between ESG performances and Value Added. Specifically, we analyzed two groups of companies (i.e., those with and without ESG ratings) and how they create and distribute value among different stakeholders.

This research paper is broadly divided into eight sections: Section 2 briefly introduces the concept of value in stakeholder theory. Section 3 reviews the literature on the areas of ESG and value creation for stakeholders. The next sections explain the methodology and research design of this study (Section 4) and our results and main findings (Section 5). Section 6 briefly discusses the results, while Section 7 provides our conclusions, as well as recommendations for managers and researchers in this area. Limitations and pathways for further research are given in the last section. 


\section{The Concept of Value in Stakeholder Theory}

From the beginning, it was clear that, following the stakeholder approach, the aim of a company aim was (and still is) to create value for stakeholders [26]. Indeed, stakeholder theory envisages a firm as being engaged with stakeholders in joint value creation. Even if this is a pillar on which the theory is built, what still remains partially uncovered is what value creation means and to which 'value(s)' we are referring [15]. Answering these questions is essential for the consistent and useful application of the stakeholder perspective: How could a stakeholder management approach advance without a reliable valuation of the outcomes of these managerial policies?

Since the introduction of the stakeholder view of corporations, Chakravarthy [27] highlighted the shortcomings of considering performance measures only focused on shareholder welfare and advocated for multi-stakeholder performance measurement systems. Conversely, due to its multidimensional nature, Jensen [28] questioned the possibility of considering stakeholder management as a specific theory in business studies. For this author, the presence of a mixture of non-comparable dimensions could had prevented the univocal assessment of managerial actions, a limitation that rendered the theory unfeasible. On the other hand, Jensen proposed stakeholder management as a way of pursuing 'Enlightened Shareholder Maximization,' in order to obtain maximum sustainable wealth for shareholders [28].

This approach to stakeholder management can be considered 'instrumental' to the principal goal of a company - namely, to maximize profit (for instrumental approaches to CSR - Corporate Social Responsibility and stakeholder management, see, e.g., [11,29]—and perfectly reflects the 'shareholder primacy' in corporate purpose. The shift towards a real and concrete stakeholder-oriented corporate purpose necessitated an 'enlargement' of shareholder views on value creation assessment systems [30,31].

These ideas renewed an interest in accounting-proxy stakeholder research, with a specific focus on defining and measuring 'stakeholder value' [30]. This line also contributes to reflections on the notion of stake which, rather than being limited to economic considerations, also extends to the wellbeing of all stakeholders affected by corporate actions, as the following quote highlights:

“[ ... ] stakeholder theorists have argued that different kinds of value may need to be simultaneously considered in decision making, and not only in so far they contribute to the maximization of profit" [14] (p. 353).

In other words, this view advances the idea that "multiple measures of firm performance" are superior to just one (i.e., financial returns) [12] (p. 118). In particular, Harrison and Wicks introduced a stakeholder view of value focused on stakeholder utility, as associated with the actual goods and services received and produced, organizational justice, affiliation, and perceived opportunity costs. These authors underlined that such factors that may drive value (more precisely, they refer to 'utility') for stakeholders include both material components (i.e., the economic value of goods and services provided by the firm) and immaterial (non-monetary) elements (i.e., the benefits associated with engaging in organizations that respect norms of fairness and reciprocity, organizational justice, and/or that exhibit characteristics that are consistent with issues relating to stakeholder value and organizational affiliation) [12]. In a similar way, Lankoski, Smith, and Van Wassenhove [32] (p. 228) defined stakeholder value as "the subjective judgment of a stakeholder, occurring at the individual level, of the total monetary and non-monetary utility experienced as a result of some decision or action by an organization".

The following words of Antonio Argandoña summarize the concept that we wish to stress:

"If the value created in companies is not just of one type, but of several, it is possible to find better ways of creating economic and non-economic value in a sustained way. So that all the stakeholders, who help to create that value, also share in its enjoyment, albeit in different and changing ways over time, so that 
the economic optimum (efficiency criterion) is guaranteed and management is improved" [15] (p. 10).

Value creation, valuation, and measurement is, therefore, a crucial issue in stakeholderrelated approaches; a topic that still needs to be fully developed [16,30].

With this paper, we would like to contribute to the debate on the assessment and measurement of value creation for stakeholders. To do so, we assess two relevant ways to measure value for stakeholders-that is, ESG ratings and Value Added-and their relationships.

\section{Measuring Value Creation for Stakeholders: ESG Rating and Value Added}

As Searcy [33] emphasized, stakeholders play different roles in setting measurement initiatives (e.g., indicators, ratings, and reporting standards) in an attempt to cover sustainability issues in a manner that satisfies their need for information. Indeed, a desired purpose of these kind of initiatives is accountability to key stakeholders [34].

Linked with the growth of responsible investments around the world (http:/ / www. eurosif.org/; https:/ / www.ussif.org/trends), ESG ratings have gained more and more relevance. This practice consists of rating companies based on information regarding a number of ESG issues, mainly from a qualitative perspective. This information is then used to make investment decisions and to select those companies that score positively, in terms of ESG aspects. The assumption is that investors select the "best" companies, in terms of their environmental, social, and governance components.

ESG ratings have been considered a good "proxy" of social responsibility [22] and/or stakeholder social responsibility [30], as they capture evidence regarding how firms treat their stakeholders [2], their impact on the environment, and how they are governed. Indeed, the content of the various metrics that ESG ratings usually adopt includes several stakeholder-related issues, as shown in the following definitions reported in Refinitiv's ESG scoring methodology (June 2019):

"The Workforce Score measures a company's effectiveness towards job satisfaction, a healthy and safe workplace, maintaining diversity and equal opportunities and development opportunities for its workforce";

"The Human Rights Score measures a company's effectiveness towards respecting the fundamental human rights conventions";

"The Community Score measures the company's commitment towards being a good citizen, protecting public health and respecting business ethics";

"The Management Score measures a company's commitment and effectiveness towards following best practice corporate governance principles"; while the

"Emission Reduction Score measures a company's commitment and effectiveness towards reducing environmental emissions in the production and operational processes".

The utility of the rating as an instrumental and strategic element has been empirically tested (see, e.g., [35-38]). In particular, ESG ratings have typically been used in stakeholderbased research to uncover whether high levels of stakeholder performance are associated with high levels of financial performance (see, e.g., $[17,19,39,40]$ ) and it was concluded via meta-analysis that, in the majority of the studies, the relationship between ESG ratings and financial performances was positive. If we look back to all the studies that investigated, in a broader way, the relationships between CSR (or social and/or environmental) performance and financial performance (see, e.g., [35,41-43]), the results are certainly complex and nuanced, but very focused on a shareholder value creation perspective. In this line, the problem, from our point of view, appears when we move from the search of the effects of the ESG rating, to understanding their efficacy in capturing stakeholder value creation.

Despite the fact that defining "value creation" for stakeholders requires a thorough understanding of their needs and expectations, as obtained through specific engagement initiatives, the concept of value creation itself remains very blurry.

In their model of essential stakeholder synergies for sustainable competitive advantage, Tantalo and Priem [13] considered the social purpose of corporations, in terms of 
value creation for stakeholders. In this case, the "S" component of ESG is particularly relevant. Furthermore, Adams [44] emphasized that the presence of suitable corporate governance and an appropriate strategy to assess ESG risks and opportunities (and the related reporting) influences value creation for stakeholders. Contributing to ecological aspects-for example, by reducing negative externalities to the environment-creates value for stakeholders and aligns the business models of companies with the sustainable development of markets and society (see, e.g., the cases published by Schaltegger et al. [45]). Therefore, ESG ratings seem to have the potential to measure at least some aspect of value creation for stakeholders.

What still seems to lack in ESG ratings is a holistic view of value creation and distribution. Indeed, stakeholder theory envisages a firm as being engaged with stakeholders in joint value creation. It is exactly thanks to the support and engagement of all the stakeholders that a company can create value. Specifically, stakeholders contribute (with their work, money, and so on) to the purpose of a company and, as such, they have the right to be compensated with value. In this aspect, Freeman [46] specified that the total value that a firm creates is a function of the value created for customers, suppliers, financiers, employees, and communities. It is exactly at the moment of producing goods or providing services that a company creates value(s) and distributes them to different stakeholders as remuneration for their participation. A fair value creation process asks for a fair distribution of value during its realization. The value generated for and recognized by customers should be distributed ex-ante to different stakeholders that contribute with their work, capital, infrastructure, and so on, to this economic process. Indeed, an emerging social issue linked to justice and equality is distributional fairness [25]:

"High levels of economic inequality being witnessed around the world are a result of value distribution being skewed toward some of these actors (namely the stakeholders) at the expense of others" [16] (p. 984).

Companies assume a crucial role in both wealth creation and distribution. Specifically, they create value through the production of goods and services that customers find 'valuable' and that they are willing to pay for [47]. Theoretically, the lower the production cost, the higher the value a company is able to create. However, the various strategies that a company could implement to minimize costs and maximize revenues could include the intention of "wealth appropriation", which is namely an attempt to keep as much wealth as possible for the company and its shareholders, to the detriment of other stakeholders [48]. This could include practices such as tax minimization, at the expense of the community, or a reduction of labor costs, with an associated negative impact on employees. Therefore, it is crucial to focus on the distribution of value, that is, on the allocation of wealth among those who have contributed to value creation [16].

Traditionally, both the economic and accounting/accountability literature has identified the concept of Value Added as a potential tool for representing the ability of an organization to create and distribute value to key stakeholders. Value Added is calculated by deducting bought-in goods and services from net turnover [49,50]. It represents the increase in wealth generated from the productive use of resources prior to its distribution among key stakeholders [51]. In this sense, it spotlights the fact that the generation of wealth in a company is the result of the "collective effort of all its stakeholders, i.e., capital providers, employees, the government, and society" [25,52]. In fact, the concept of Value Added reveals components that contribute to the creation of economic wealth and its distribution. Although Value Added is not distributed to all stakeholders-just to some of them which are essential to the firm, such as shareholders, public authorities, financers, and employees - it can be considered a proxy of how the company is managed for the benefit of its stakeholders [53]. Value Added can thus also be considered an appropriate indicator of the economic as well as the social role of a company within society $[25,52]$.

As emphasized above, a number of studies have focused on the relationships between ESG and financial performance (mainly understood as value creation for shareholders) (see, e.g., [22,40,54]). Yet, to the best of our knowledge, no attention has been paid to the 
link between ESG ratings and Value Added and its distribution among stakeholders. In particular, while ESG may be considered a proxy of 'qualitative' and 'social' value for stakeholders, Value Added can shed light on both the creation and distribution of economic value. The relationships between ESG performance and value created and distributed among stakeholders are, therefore, crucial in fully understanding the contributions that companies make to societies and stakeholders. For this reason, the next section addresses empirical research into the relationship between these two dimensions. Specifically, we test six different hypotheses.

First of all, we advance the idea that there may be a positive and robust relationship between ESG ratings and Value Added. The basis of this hypothesis is that we envision that the most socially responsible companies-in terms of ESG ratings-are also more virtuous in economic value creation (measured in terms of Value Added). In other worlds, ESG ratings are also able to capture companies with higher economic value creation for stakeholders. Therefore, we state that:

Hypothesis 1 (H1). There is a positive and robust relationship between ESG performance and Value Added.

Then, considering that not all companies have been ranked by ESG rating providers, we consider that those captured by ESG ratings are also the best performers, in terms of Value Added (VA), and that the ability to add value increases with an increase of the ESG score. In other words:

Hypothesis 2 (H2). ESG companies have a higher VA, compared to non-ESG companies.

and

Hypothesis 3 (H3). VA increases with an increase of ESG ratings.

Additionally, an alternative way to assess the performance of companies is to measure their efficiency, that is, the balance between input and outputs. We consider capital as input from the company's owners and different values created for stakeholders (employees, shareholders, financiers, and governmental) and/or retained in the company as outputs. We advance the hypothesis that when the relative efficiency measure is higher, the ESG score should also be higher. Thus, we state that:

Hypothesis 4 (H4). Relative Social Efficiency increases with rising ESG ratings.

Furthermore, after having analyzed the value creation side, we would like to better understand some value distribution aspects. In the last part of our analysis, we focus on the relationships between ESG ratings and Value Added distribution among different stakeholders. Specifically, we advance the idea that companies that have distinguished themselves by choosing to undergo ESG evaluation should also be distinguished in the distribution of Value Added (H5). This difference exists not only as far as the total Value Added distributed to stakeholders, but also in the specific composition, relating to how value is distributed among stakeholders (H6).

Hypothesis 5 (H5). The Value Added distribution differs between ESG and non-ESG companies.

Hypothesis 6 (H6). There is a significant difference between companies with an ESG score and those without a score, in relation to their Value Added for stakeholders (employees, shareholders, financiers, government, and retained).

The following paragraphs first detail the data used and how we decided to test our hypotheses. Then, we provide the results of our analysis. 


\section{Data and Methodology}

\subsection{Population}

For the purpose of our analysis, we used data from Thomson Reuters EikonTM, which provides both a comprehensive platform for the assessment of corporate performance and one of the most comprehensive ESG databases in the industry, covering over $70 \%$ of the global market cap (around 7000 companies globally). The possibility of using the same source for both economic-financial records and ESG ratings allowed for better homogeneity of the data.

The data were downloaded from EIKON on 1 August 2019 for all companies in the Euro zone and for all sectors (with the exclusion of Healthcare and Financial Services sectors).

The choice to focus our analysis on European companies was based on different motivations. Firstly, to ensure the homogeneity of the sample, as companies mainly belonged to "unified markets," with similar social, environmental, and economic regulations. Furthermore, the European Union has been promoting CSR for a long time, as well as (more recently) sustainability. A particular relevance has been assigned to the need for common regulations regarding CSR and sustainability-related issues, as well as their accountability. Some examples are the Directive 2014/95/EU on the disclosure of non-financial and diversity information by certain large European undertakings and groups and the recent commitment to enhance the ESG transparency of benchmark methodologies.

After selecting the "valid data" (which excluded companies with total revenues $<$ or $=0$ ), we obtained a population of 1932 companies, 399 of which had ESG ratings and 1533 were without ESG analysis. All countries, company sizes, and sectors included were aligned with the real data. The analysis was conducted for 2018 data.

We used the IBM SPSS 24 software for statistical analysis. Financial services were excluded, due to the specificity of the activities and for the particular structure of their financial statements, while healthcare was ruled out due to "anomalous" performances. In fact, most of the companies reported a negative "net income before distribution", which means that the Value Added was negative for most of these companies.

\subsection{Collected Variables}

The main data used in the analysis were ESG Scores and Approximated Value Added (creation and distribution), as the aim of the paper was to investigate the relationships between these two components of value for stakeholders. In the following, we describe how they were calculated.

ESG Scores: Thomson Reuters uses ESG Scores from Refinitiv, where information publicly reported by companies is collected and analyzed through more than 400 different ESG metrics. These metrics are grouped into 10 categories. A combination of the 10 categories, weighted proportionately to the count of measures within each category, formulates the three Pillar Scores ( $E=$ environmental, $S=$ social, and $G=$ governance) and the final overall ESG Score, which reflects the company's ESG performance, commitment, and effectiveness-Environmental, Social, and Governance (ESG) Scores from Refinitiv, June 2019.

Approximated Value Added $\left(\mathrm{VA}^{*}\right)$ creation and distribution: Traditionally, accounting studies calculate Value Added by deducting 'outside acquisitions' from net turnover, which includes all expenses incurred in the purchase of goods and services from other companies $[24,25,49,50]$. Therefore, the correct calculation of Value Added requires reclassifying the Income Statement following specific criteria and using detailed internal data. Unfortunately, databases often do not provide all the specific information needed for this kind of reclassification; in particular, 'outside acquisitions' are often omitted. Consequently, we used the concept of "Approximated Value Added" (VA*), such as the difference between the Total Revenue and the Costs of bought-in goods and services, as presented in formal (and published) Annual Income Statements.

Then, we calculated the wealth distributed to different stakeholders, in terms of employee labor costs, taxes paid to governments, interest paid to investors, dividends to 
shareholders, the percentage of profit or loss for minorities, and the amount of money retained by the company for future activities. In order to do this, we collected and analyzed data provided by the Annual Financial and Income Statements.

The variables used in our analysis were as follows:

- $\quad$ VA$^{*}$ (Approximated Value Added) $=$ Net Revenues-Suppliers (purchase of goods and services);

- VA to employees/workers;

- $\quad$ VA to governments;

- VA to investors (not shareholders);

- VA to shareholders (including minorities);

- VA retained by the company;

\subsection{Method of Analysis}

We used the Pearson correlation test, with the aim to assess the relationships of pairs of continuous variables (ESG score and Approximated Value Added, in its different forms). Some descriptive analysis was done to analyze the distribution values among stakeholders with some different means tests applied to indicate if there were significant differences between variables in the different groups. We used the Fisher-Snedecor statistic with the purpose of testing for the equality of two populations (ANOVA): companies with ESG values and companies without such values.

To understand if the ESG is a good proxy for value creation for stakeholders, we checked the relative social efficiency (H4) through Data Envelopment Analysis (DEA) using the Banxia Frontier Analyst 4.0 software. This is a suitable method, as DEA clearly shows the ultimate distance to the efficient relative frontier [55], helping responsible investors and decision-makers to improve their efficiency decisions towards value creation for stakeholders. DEA is especially appropriate when there is no unique variable to achieve from Decision Making Units or at a DMU level (i.e., firm level) [56], which is useful for companies that, as in this case, accept standards based on stakeholder value creation by assessing the trade-off between eligible inputs and outputs as a deciding signal. The aim is to include the generation of value for stakeholders, based on the resources available for the purpose of the company. In this regard, the DEA output orientation model was created, indicating a maximum output increase at the current level of inputs. Variable selection was considered crucial for the purpose of our study, based on the need to assess the capacity of companies to generate value for stakeholders with the available resources [57]. Only one input was used for the initial trial: Total Equity (as the sum of all capital stock at the firm's year-end). This input was selected in line with recent developments regarding the roles of companies in society. A stakeholder approach is appropriate for a sustainable society and, therefore, it is possible to support a trade-off system between inputs and outputs, based on the creation of value [58]. For input, the equity or assets [58] linked to the outputs that represent the value generated for stakeholders (employees, government, investors, shareholders and minorities, and retained values) was used [59]. As output, we used the distribution among stakeholders, specifically: VA to workers, VA to shareholders, VA to external investors, VA to governments, and VA retained for self-financing.

The Frontier Analyst software was used, which employs a scale of 100. Considering the extent to which a company (considered as a DMU) is far from the frontier (as determined by the group of decision-making units that obtain maximum efficiency), the value falls between 100 and 0 . This method allows us to obtain relative—-but not absolute-efficiency. This methodology indicates the best relative efficiency, compared with others, in terms of generating value for stakeholders (with equity as input). 


\section{Results}

The data described above were used to test the six hypotheses mentioned above.

\subsection{The Relationship between ESG and VA*}

As stated above, we expected a positive and robust relationship between ESG ratings and Value Added, where a higher ESG is related to more Value Added created by companies. Indeed, the adoption of environmental, social, and governmental practices should permit a company to improve the quality of their management and increase their generation of value.

First of all, we analyzed the amount of Value Added produced by companies, comparing performances with ESG and without ESG, as an absolute number and per employee.

As Table 1 shows, with a significance level of $1 \%$, it was possible to establish differences in Approximated Value Added between companies without ESG and companies with ESG (regardless of their ESG level). It is important to consider the absolute number, as it is the value generated for society. Those companies that applied ESG obtained a higher added value in 2018. However, it is also important to analyze the relative added value. We calculated added value based on the number of employees of each company and using this relative ratio, we controlled for the size of the company. As shown in Table 1, ESG companies with a higher ESG obtained a higher added value absolutely, but not relatively. Therefore, it seems that there may have been a positive relationship between ESG and added value in 2018 - but not when analyzing the relative value added-based on value creation per employee. This result is particularly interesting and deserves further investigation.

Table 1. Value Added (VA*) for ESG (Environmental, Social, and Governance) companies vs. nonESG companies: Absolute and per employee.

\begin{tabular}{cccc}
\hline ESG Variable & Value Added 2018* & $\begin{array}{c}\text { Value Added 2018 } \\
\text { per Employee } \\
\text { Mean }\end{array}$ & $\begin{array}{c}\text { Value Added 2018 } \\
\text { per Employee } \\
\text { Standard Deviation }\end{array}$ \\
\hline Non-ESG companies & $161,879,181 €$ & $234,742 €$ & $302,139.14 €$ \\
ESG companies & $3,948,875,496 €$ & $190,875 €$ & $2,037,822.20 €$ \\
\hline${ }^{*}$ mean value is $932,084,804 € ;$ significance level at $1 \%$. & &
\end{tabular}

Table 2 shows the positive and significant correlations between Value Added and ESG scores, evidencing the relationships between all of the ESG (Environment, Social, and Governance) scores.

Table 2. Correlations between ESG ratings and Value Added (VA*): Pearson.

\begin{tabular}{|c|c|c|c|c|}
\hline & ESGo18 & ESGe18 & ESGs18 & ESGg18 \\
\hline ValueAddedAprx18 & $0.321^{* * *}$ & $0.283^{* * *}$ & $0.293^{* * *}$ & $0.175^{* * *}$ \\
\hline
\end{tabular}

Furthermore, the analysis shows that the higher the ESG, the higher the VA*. This confirms the relationship between ESG and value creation, in other words, companies that created more VA* are those that also obtained a higher ESG score. Nevertheless, the data show that a higher ESG and a higher Value Added were prevalent amongst larger companies.

In summary, we can state that our hypotheses $(\mathrm{H} 1-\mathrm{H} 3)$ were confirmed however, the possibility that company nationality or sector was the main determinant for both values reduced the relevance of the results. The size of companies was controlled for by using the value added depending on the number of employees. 


\subsection{Relative Social Efficiency and ESG Ratings}

We cannot contribute to establishing the optimum distribution of value creation, although we can indicate the most efficient relationship between inputs and outputs in value creation for stakeholders. Hypothesis 4 (H4) consists of analyzing whether those (relatively) more efficient companies had a higher ESG or if the ESG was, indeed, more related to size.

To conduct the DEA analysis, we discarded seven companies with negative equity and transformed the negative government value generation to zero, in order to analyze the statistical moment of the company only.

We checked for any significant differences between social efficiency (relative) based on generating value for stakeholders and the overall ESG rating. If companies with an ESG rating are best in class, a significant relationship between those scores should be expected. In this sense, we divided the sample into two groups: Those with a high overall ESG scores (70 points or more) and those with fewer than 70 points.

Table 3 shows that there was a very small, non-significant relationship between relative stakeholder value creation efficiency (using equity as input) and an overall ESG score. Companies with lower ESG scores had a Relative Stakeholder Value Creation Efficiency of 41.14 points (with an ESG score of 60.06). There was a positive-albeit non-significantrelationship. The remaining companies (i.e., those with higher ESG scores) generated a Relative Efficiency score of 62.27 points, correlated positively-but not significantlywith ESG scores (78.49). There was, therefore, no clear relationship between generating equity-based value for stakeholders and ESG scores. Our findings suggest that there exist doubts surrounding the relationship between ESG scores and the generation of value for stakeholders. Hypothesis 4 was not confirmed.

Table 3. Data Envelopment Analysis (DEA) Relative Social Efficiency vs. ESG scores.

\begin{tabular}{ccccc}
\hline Variables & $\mathbf{N}$ & $\begin{array}{c}\text { DEA (Relative } \\
\text { Stakeholders Value } \\
\text { Creation Efficiency) } \\
\text { Mean }(\boldsymbol{\sigma})^{*}\end{array}$ & $\begin{array}{c}\text { ESG Scores } \\
\text { Overall } \\
\text { Mean }(\boldsymbol{\sigma})\end{array}$ & $\begin{array}{c}\text { DEA Relative } \\
\text { Stakeholder Value } \\
\text { Creation Efficiency vs. } \\
\text { ESGs Score Pearson } \\
\text { Correlation }\end{array}$ \\
\hline ESG overall LOW (70 or less) & 205 & $41.14(26.03)$ & $60.06(5.89)$ & 0.13 \\
ESG overall HIGH (more than 70) & 150 & $62.27(23.47)$ & $78.49(5.61)$ & 0.07 \\
\hline
\end{tabular}

* input: equity; outputs: VA to labor, VA to shareholders (incl. minority), VA to external capital (financiers), VA to government, and VA retained for self-financing.

\subsection{Value Added Distribution in ESG and Non-ESG Companies}

To further investigate the relationship between ESG ratings and Value Added, we decided to analyze the Value Added distribution for the two different groups (companies with and without ESG ratings).

The following table (see Table 4) shows the percentages of Value Added for each stakeholder, comparing companies with an ESG score to those without one. It is clear that there were some differences, in terms of distribution, particularly regarding governmental and employee value distribution.

There were a number of significant differences regarding value creation for some stakeholders, as not all companies created value for stakeholders in the same proportion. Companies with an ESG score created less value, in terms of the labor factor, but more for governments and, in general, they retained more value for the company. Capital payment was higher in companies with an ESG score than in businesses without one. In other words, companies with an ESG score distributed more value to shareholders and retained a higher share of revenue for the future of the company, at the 'expense' of labor and financial providers (excluding shareholders). On the other hand, they contributed more to governmental expenditures. 
Table 4. Value Added (VA*) distribution (ESG vs. non-ESG companies).

\begin{tabular}{cccc}
\hline VA* Clients-Suppliers (Creation) & ESG Companies & Non-ESG Companies & F-Test (Significance Level) \\
\hline VA to labor & $53.25 \%$ & $65.35 \%$ & $65.586(0.000) * * *$ \\
VA to shareholders (incl. minority) & $8.18 \%$ & $4.14 \%$ & $0.461(0.497)$ \\
VA to external capital (financiers) & $4.20 \%$ & $6.23 \%$ & $9.578(0.002) * * *$ \\
VA to government & $6.28 \%$ & $1.76 \%$ & $22.254(0.000) * * *$ \\
VA to self-financing (Retained) & $28.09 \%$ & $22.52 \%$ & $1.838(0.178)$ \\
Total & $100 \%$ & $100 \%$ & \\
\hline
\end{tabular}

*** significant at $1 \%$.

Furthermore, Table 5 shows that the higher the ESG rating, the higher the distribution to governments and shareholders, with a lower share of value retained. There was no clear trend for labor and financial providers.

Table 5. Value Added (VA*) distribution based on ESG overall score levels.

\begin{tabular}{|c|c|c|c|c|c|c|c|}
\hline \multicolumn{2}{|r|}{ Variables } & \multirow{2}{*}{$\begin{array}{c}\text { ValueAdd- } \\
\text { edAprx18 } \\
\text { Mean }\end{array}$} & \multirow{2}{*}{$\begin{array}{c}\begin{array}{c}\text { Pct_VAEm- } \\
\text { ployees18 }\end{array} \\
\text { Mean }\end{array}$} & \multirow{2}{*}{$\begin{array}{c}\begin{array}{c}\text { Pct_VA- } \\
\text { Government18 }\end{array} \\
\text { Mean }\end{array}$} & \multirow{2}{*}{$\begin{array}{c}\text { Pct_VAIn- } \\
\text { vestors18 }\end{array}$} & \multirow{2}{*}{$\begin{array}{c}\begin{array}{c}\text { Pct_VShare- } \\
\text { holderMinority18 }\end{array} \\
\text { Mean }\end{array}$} & \multirow{2}{*}{$\begin{array}{c}\begin{array}{c}\text { Pct_VARe- } \\
\text { tained18 }\end{array} \\
\text { Mean }\end{array}$} \\
\hline & & & & & & & \\
\hline \multirow{6}{*}{$\begin{array}{l}\text { Percentile } \\
\text { Group of } \\
\text { ESGo18n }\end{array}$} & Without ESG & $161,879,181 €$ & $65.4 \%$ & $1.8 \%$ & $6.2 \%$ & $4.1 \%$ & $22.5 \%$ \\
\hline & ESGo Low & $1,504,715,220 €$ & $52.6 \%$ & $5.4 \%$ & $5.1 \%$ & $6.1 \%$ & $30.9 \%$ \\
\hline & ESGo MidLow & $2,751,897,862 €$ & $54.9 \%$ & $6.0 \%$ & $3.2 \%$ & $7.6 \%$ & $28.4 \%$ \\
\hline & ESGo MidHigh & $4,201,544,991 €$ & $51.7 \%$ & $6.8 \%$ & $4.6 \%$ & $9.4 \%$ & $27.5 \%$ \\
\hline & ESGo High & $7,337,343,912 €$ & $53.7 \%$ & $7.1 \%$ & $4.0 \%$ & $9.6 \%$ & $25.6 \%$ \\
\hline & Total & $932,084,804 €$ & $62.9 \%$ & $2.7 \%$ & $5.8 \%$ & $5.0 \%$ & $23.7 \%$ \\
\hline
\end{tabular}

Hypotheses 5 and 6 were, therefore, confirmed.

\section{Discussion}

The concept of Value Added was conceived as (and still remains) an important financial accounting tool for different analyses, for example, in order to measure the efficiency of labor and investments.

Since the pioneering times of social responsibility information, Value Added Statements have also been proposed in order to emphasize wealth creation and distribution among stakeholders (see, e.g., the Praxis document edited in Summer 1976 and published in Der Betrib in 1978 [60]) as guidelines for future social accounts of German firms and the Italian Social Accounting Standard of Gruppo Bilancio Sociale [61]. However, in recent times, they seem to have been surpassed by other specific indicators.

Despite the limitation of not considering all the stakeholders in wealth distribution (e.g., consumers, sub-contractors, and economic externalities are not considered in this value) in our analysis, the utility of Value Added emerges as a potential and important tool for representing an organization's capacity to create value for key stakeholders. Such potential emerges when we compare Value Added with more widespread tools for measuring stakeholder value creation, such as ESG ratings. In fact, the data evaluated herein revealed that, although ESG is theoretically considered a social responsibility proxy, it does not represent a comprehensive measure of value creation for stakeholders.

More specifically, our results demonstrated that the Value Added created by companies with ESG ratings was significantly higher than those generated by companies without ESG ratings. This is an important result, as the total value created is a proxy of the contribution that these companies provide to society as a whole. We can, therefore, state that ESG companies cumulatively generated more value than non-ESG companies. This could be due to the size of companies with ESG ratings, that is, only the biggest companies have the resources or interest to submit their performance to external valuation. However, if we look at the Value Added per employee, the position is opposite. Companies with ESG ratings had lower value added, compared with their peers without ESG ratings (Table 1). This result could be due to different reasons for example, there could be a sector effect, as 
companies with ESG ratings tended to belong to more labor-intensive sectors, or the effect could be ascribed to other policies (related or not to employees) adopted by companies, such as the more intensive use of sub-contracting or outsourcing. Further investigations are needed in order to verify these results in more depth.

Furthermore, considering stakeholder theory from an ontological perspective, companies can be seen as a relational system in which value is created not only for those that invest their capital, but also for other stakeholders $[12,13,26,30]$. Based on this idea, another fundamental aim of this paper was to demonstrate whether companies with an ESG rating have a different distribution structure than companies that do not.

With respect to this matter, it was very interesting to notice that the distribution of Value Added among stakeholders was significantly different between the two groups (Table 4). Companies with ESG ratings paid less attention to employees and financiers and more to governments and to the ownership, in term of both dividends distributed and value retained by the company (i.e., self-financing). These results confirm the position of previous studies, in which ESG ratings were considered to be an instrumental and strategic tool to leverage financial performance $[17,19,39]$ - in particular, to the benefit of shareholdersand supports our (and other authors) call for new and broader measurement systems. However, this does not answer the need to shift from a shareholder-focused perspective to one which is more stakeholder-oriented [2,16].

The principal aim of our study was, in fact, to show whether ESG scores are a good proxy for social investors who are concerned about value creation for stakeholders. Considering our results, we can state that ESG indices cannot replace all value-creation indicators for stakeholders but, rather, should serve as just one of the components.

Once again, our results support the need for multidimensional performance measures and measurement tools to assess the performance of companies that depend on the complex and multidimensional concept of "stake" [12-15].

These results have significant implications, both for companies and their stakeholders. Companies should be aware that they need a plentiful set of tools to report on their performance toward stakeholders, such that more traditional reporting forms (e.g., financial reporting) can also contribute to assessing, valuating, and reporting on stakeholder value creation, if properly adapted.

Similarly, other stakeholders that need (or want) to make decisions about companies, based on their capability to create value for a broad number of stakeholders, should not focus their analysis on only ESG ratings but instead must integrate other information. We advance the idea that Value Added could provide a suitable approach to integrate issues related to value creation and distribution among stakeholders or, at least, among some key ones.

\section{Conclusions}

The recent revision of the Business Roundtable Statement on the Purpose of the Corporation has renewed the debate on the meaning and measurement of value creation for stakeholders. To shift from a shareholder-oriented to a broader stakeholder-oriented purpose for corporate needs, among other things, we must rethink company performance measurement systems. This paper aims to contribute to this debate by analyzing the relationships between two possible ways to measure value for stakeholders: ESG ratings and Value Added.

ESG ratings have been increasingly used as a performance indicator for corporate social responsibility and good company-stakeholder relationships. Despite that, ESG scores are mostly based on information on how a good and sustainable business should act from a social, environmental, and governance perspective, without any specific quantitative consideration about how the economic value is created and distributed along the economic process. For this reason, we advanced the idea to consider a more strictly economic dimension (i.e., the Value Added), in order to assess value creation and distribution. 
In this paper, using data of European companies from 2018, we investigated the relationship between ESG ratings and Value Added. The analysis was conducted using the frontier methodology, combined with means comparison. We delved more deeply into ESG companies than previous studies by including the value creation for stakeholders, based on Value Added. This paper contributes to the debate on stakeholder theory and corporate objectives to create value for all stakeholders, not merely for shareholders.

Our findings are not similar to those obtained previously, in which the ESG score has been deemed universal and of major use for social purposes. Indeed, despite the fact that we found a positive relationship between ESG and Value Added, this seemed to be more related to a company's size than to its ESG performance, as the results were the opposite when controlling for company size. Therefore, we conducted a Data Envelopment Analysis (DEA) using the Banxia Frontier Analyst software, in order to analyze differences in social efficiency between companies with and without ESG ratings. More precisely, we balanced equity as input and stakeholder value creation (in terms of VA to workers, VA to shareholders, VA to external capital, VA to governments, and VA to self-financing) as outputs. The analysis demonstrated the absence of a direct relationship between Relative Social Efficiency and ESG scores. This means that, despite a good performance of a company from a social, environmental, and governance point of view, ESG ratings are not able to capture or reflect the economic and social aspects of value creation and distribution for stakeholders.

Our results advise against the use of the ESG social score as the only proxy for assessing the social purpose of a company. Despite the fact that it usually reflects the social culture or worries of the company, is not able to well reflect the value creation for stakeholders.

Furthermore, several important and interesting findings were reported in this study. For example, it appears that not all companies adopted the stakeholder value creation model. There were a number of significant differences in European companies, in relation to value creation for worker, governmental, and capital factors.

The results of our study have important implications, both for researchers and for practitioners. Our data warn investors, policy-makers, and society in general, about the content of the "S" of ESG ratings. Specifically, we posit that the social purpose of a corporation should also include considerations regarding value added generation and distribution for stakeholders. Hence, there is a proven need to develop information, in addition to ESG scores, as different actors interested in value creation for stakeholders should not be fully satisfied by ESG scores as a proxy. We suggest that Value Added could provide a good proxy, giving emphasis on financial statements as a powerful source of useful information. This serves as a good starting point for future research in this area. Furthermore, our results also shed light on both the risk of greenwashing and the managerial capture of some ESG ratings or/and the real ethical and responsibility motivations of some companies. These findings are obviously only a small sign of the possible ethical misuse of ESG. Therefore, we recommend asking for a detailed examination of a company's accountability procedures and concrete behavior.

\section{Limitations and Future Research Lines}

We should point out that the main limitations of this paper stem partly from the technique employed and partly from the data used. Despite its advantages, DEA answers the question of whether a unit is efficient or not but fails to distinguish between units with a score of 100 and others that are relatively less efficient. In addition, DEA efficiency scores are highly sensitive to the selected inputs and outputs therefore, a small change could produce a different result. On the other hand, our analysis was based on data for a single year and only for European companies. It would be useful to analyze coherency over a longer period, applying a multivariable analysis that explains the variables affecting companies with ESG scores, in order to obtain deeper insight. However, it is first necessary to clarify the position of results in unique data to understand the situation properly; 
therefore, annual analysis will allow for more robustness in future longitudinal works. In further studies, the geographical context could also be expanded to a more global scope, where sector-by-sector and country-by-country analyses could be incorporated. In future, this study could be replicated, in order to assess the effect of the current pandemic on corporate performance, both in terms of ESG and value added and their connections.

All of these limitations open new avenues for further research. A longitudinal analysis, but also an analysis of the equilibrium of distributed value for stakeholders and/or a country comparison regarding the value creation in stakeholder culture with a size-sector control will be relevant to contribute to sustainability ratings and, in particular, to assess the social purpose of companies.

Author Contributions: Conceptualization, S.S., L.S.-J., J.L.R. and G.R.; Data curation, S.S., L.S.-J. and J.L.R.; Formal analysis, S.S., L.S.-J. and J.L.R.; Funding acquisition, L.S.-J., J.L.R. and G.R.; Investigation, S.S., L.S.-J. and J.L.R.; Methodology, S.S., L.S.-J. and J.L.R.; Supervision, G.R.; Writingoriginal draft, S.S., L.S.-J., J.L.R. and G.R.; Writing-review and editing: S.S., L.S.-J., J.L.R. and G.R. All authors have read and agreed to the published version of the manuscript.

Funding: This research was funded by the University of Bergamo (Italy) Programma STaRs "Stars Supporting Talented Researchers"-Azione 2: "Grants for Visiting Professor and Scholar Incoming"2018 and by the University of the Basque Country (UPV/EHU), grant number US20/11.

Institutional Review Board Statement: Not applicable.

Informed Consent Statemen: Not applicable.

Data Availability Statement: Not applicable.

Acknowledgments: We thank the four anonymous reviewers whose suggestions helped improve and clarify this manuscript.

Conflicts of Interest: The authors declare no conflict of interest.

\section{References}

1. BRT Business Roundtable. Statement on the Purpose of a Corporation. 2019. Available online: https://www.businessroundtable. org/business-round table-redefines-the-purpose-of-a-corporation-to-promote-an-economy-that-serves-all-americans (accessed on 26 January 2021).

2. Harrison, J.S.; Phillips, R.A.; Freeman, R.E. On the 2019 business roundtable "Statement on the purpose of a corporation". J. Manag. 2020, 46, 1223-1237. [CrossRef]

3. Freeman, R.E. Strategic Management: A Stakeholder Approach; Pitman: Boston, MA, USA, 1984; ISBN 978-0-273-01913-8.

4. Freeman, R.; Reed, D. Stockholders and stakeholders: A new perspective on corporate governance. Calif. Manag. Rev. 1983, 25, 88-106. [CrossRef]

5. Freeman, R.E. Divergent stakeholder theory. Acad. Manag. Rev. 1999, 24, 233-236. [CrossRef]

6. Goodpaster, K.E. Business ethics and stakeholder analysis. Bus. Ethics Q. 1991, 1, 53-73. [CrossRef]

7. Evan, W.M.; Freeman, R.E. A stakeholder theory of the modern corporation: Kantian capitalism. In Business Ethics: Readings and Cases in Corporate Morality; Hoffman, W.M., Frederick, R.E., Eds.; McGraw-Hill: New York, NY, USA, 1993.

8. Boatright, J.R. Fiduciary duties and the shareholder-management relation. Bus. Ethics Q. 1994, 4, 393-407. [CrossRef]

9. Goodpaster, K.E.; Holloran, T.E. In defense of a paradox. Bus. Ethics Q. 1994, 4, 423-429. [CrossRef]

10. Freeman, R.E. The politics of stakeholder theory: Some future directions. Bus. Ethics Q. 1994, 4, 409-421. [CrossRef]

11. Donaldson, T.; Preston, L.E. The stakeholder theory of the corporation: Concepts, evidence, and implications. Acad. Manag. Rev. 1995, 20, 65-91. [CrossRef]

12. Harrison, J.S.; Wicks, A.C. Stakeholder theory, value, and firm performance. Bus. Ethics Q. 2013, 23, 97-124. [CrossRef]

13. Tantalo, C.; Priem, R.L. Value creation through stakeholder synergy. Strateg. Manag. J. 2016, 37, 314-329. [CrossRef]

14. Van der Linden, B.; Freeman, R.E. Profit and other values: Thick evaluation in decision making. Bus. Ethics Q. 2017, 27, 353-379. [CrossRef]

15. Argandoña, A. Stakeholder Theory and Value Creation; IESE Business School Working Paper No. 922; IESE Business School: Barcelona, Spain, 2011.

16. Bapuji, H.; Husted, B.W.; Lu, J.; Mir, R. Value creation, appropriation, and distribution: How firms contribute to societal economic inequality. Bus. Soc. 2018, 57, 983-1009. [CrossRef]

17. Choi, J.; Wang, H. Stakeholder relations and the persistence of corporate financial performance. Strateg. Manag. J. 2009, 30, 895-907. [CrossRef] 
18. Henisz, W.J.; Dorobantu, S.; Nartey, L.J. Spinning gold: The financial returns to stakeholder engagement. Strateg. Manag. J. 2014, 35, 1727-1748. [CrossRef]

19. Hillman, A.J.; Keim, G.D. Shareholder value, stakeholder management, and social issues: What's the bottom line? Strateg. Manag. J. 2001, 22, 125-139. [CrossRef]

20. Sisodia, R.; Sheth, J.N.; Wolfe, D.B. Firms of Endearment: How World-Class Companies Profit from Passion and Purpose, 2nd ed.; Pearson: Upper Saddle River, NJ, USA, 2014; ISBN 978-0-13-338259-4.

21. Ronnegard, D.; Smith, N.C. Shareholder primacy vs. stakeholder theory: The law as constraint and potential enabler of stakeholder concerns. In Cambridge Handbook of Stakeholder Theory; Harrison, J.S., Barney, J.B., Freeman, R.E., Phillips, R.E., Eds.; Cambridge University Press: Cambridge, UK, 2019; pp. 117-131.

22. Brogi, M.; Lagasio, V. Environmental, social, and governance and company profitability: Are financial intermediaries different? Corp. Soc. Responsib. Environ. Manag. 2019, 26, 576-587. [CrossRef]

23. Freeman, R.E.; Velamuri, S.R. A new approach to CSR: Company stakeholder responsibility. In Corporate Social Responsibility; Kakabadse, A., Morsing, M., Eds.; Palgrave Macmillan: London, UK, 2006; pp. 183-216. ISBN 978-1-349-52066-4.

24. Davis, E.; Kay, J. Assessing corporate performance. Bus. Strategy Rev. 1990, 1, 1-16. [CrossRef]

25. Haller, A.; van Staden, C.J.; Landis, C. Value added as part of sustainability reporting: Reporting on distributional fairness or obfuscation? J. Bus. Ethics 2018, 152, 763-781. [CrossRef]

26. Post, J.E.; Preston, L.E.; Sauter-Sachs, S. Redefining the Corporation: Stakeholder Management and Organizational Wealth; Stanford University Press: Redwood City, CA, USA, 2002; ISBN 978-0-8047-4310-5.

27. Chakravarthy, B.S. Measuring strategic performance. Strateg. Manag. J. 1986, 7, 437-458. [CrossRef]

28. Jensen, M.C. Value maximization, stakeholder theory, and the corporate objective function. Bus. Ethics Q. 2002, 12, 235-256. [CrossRef]

29. Garriga, E.; Melé, D. Corporate social responsibility theories: Mapping the territory. J. Bus. Ethics 2004, 53, 51-71. [CrossRef]

30. Freeman, R.E.; Harrison, J.S.; Wicks, A.C.; Parmar, B.L.; de Colle, S. Stakeholder Theory: The State of the Art; Cambridge University Press: Cambridge, UK, 2010; ISBN 978-1-139-48411-4.

31. Agle, B.R.; Donaldson, T.; Freeman, R.E.; Jensen, M.C.; Mitchell, R.K.; Wood, D.J. Dialogue: Toward superior stakeholder theory. Bus. Ethics Q. 2008, 18, 153-190. [CrossRef]

32. Lankoski, L.; Smith, N.C.; Van Wassenhove, L. Stakeholder judgments of value. Bus. Ethics Q. 2016, 26, 227-256. [CrossRef]

33. Searcy, C. Measuring enterprise sustainability. Bus. Strategy Environ. 2016, 25, 120-133. [CrossRef]

34. Gray, R.; Adams, C.; Owen, D. Accountability, Social Responsibility and Sustainability: Accounting for Society and the Environment; Pearson Higher Education: London, UK, 2014.

35. Miralles-Quirós, M.M.; Miralles-Quirós, J.L.; Redondo Hernández, J. ESG performance and shareholder value creation in the banking industry: International differences. Sustainability 2019, 11, 1404. [CrossRef]

36. Miralles-Quirós, M.M.; Miralles-Quirós, J.L.; Redondo-Hernández, J. The impact of environmental, social, and governance performance on stock prices: Evidence from the banking industry. Corp. Soc. Responsib. Environ. Manag. 2019, 26, 1446-1456. [CrossRef]

37. Landi, G.; Sciarelli, M. Towards a more ethical market: The impact of ESG rating on corporate financial performance. Soc. Responsib. J. 2019, 15, 11-27. [CrossRef]

38. Ting, I.W.K.; Azizan, N.A.; Bhaskaran, R.K.; Sukumaran, S.K. Corporate social performance and firm performance: Comparative study among developed and emerging market firms. Sustainability 2020, 12, 26. [CrossRef]

39. Mattingly, J.E. Corporate social performance: A review of empirical research examining the corporation-society relationship using Kinder, Lydenberg, Domini social ratings data. Bus. Soc. 2017, 56, 796-839. [CrossRef]

40. Friede, G.; Busch, T.; Bassen, A. ESG and financial performance: Aggregated evidence from more than 2000 empirical studies. J. Sustain. Financ. Invest. 2015, 5, 210-233. [CrossRef]

41. Margolis, J.D.; Elfenbein, H.A.; Walsh, J.P. Does It Pay to Be Good ... and Does It Matter? A Meta-Analysis of the Relationship between Corporate Social and Financial Performance; Social Science Research Network: Rochester, NY, USA, 2009.

42. Orlitzky, M.; Schmidt, F.L.; Rynes, S.L. Corporate social and environmental responsibility: A meta-analysis. Organ. Stud. 2003, 24, 403-441. [CrossRef]

43. King, A.A.; Lenox, M.J. Does it really pay to be green? An empirical study of firm environmental and financial performance: An empirical study of firm environmental and financial performance. J. Ind. Ecol. 2001, 5, 105-116. [CrossRef]

44. Adams, C.A. Conceptualising the contemporary corporate value creation process. Account. Audit. Account. J. 2017, 30, 906-931. [CrossRef]

45. Schaltegger, S.; Freund, F.L.; Hansen, E.G. Business cases for sustainability: The role of business model innovation for corporate sustainability. Int. J. Innov. Sustain. Dev. 2012, 6, 95-119. [CrossRef]

46. Freeman, R.E. The new story of business: Towards a more responsible capitalism. Bus. Soc. Rev. 2017, 122, 449-465. [CrossRef]

47. Bowman, C.; Ambrosini, V. Value creation versus value capture: Towards a coherent definition of value in strategy. Br. J. Manag. 2000, 11, 1-15. [CrossRef]

48. Bapuji, H. Individuals, interactions and institutions: How economic inequality affects organizations. Hum. Relat. 2015, 68, 1059-1083. [CrossRef] 
49. Renshall, M.; Allan, R.; Nicholson, K. Added Value in External Financial Reporting: A Study of Its Aims and Uses in the Context of General Purpose Financial Reports; Institute of Chartered Accountants in England and Wales: London, UK, 1979.

50. Riahi-Belkaoui, A. The information content of value added, earnings, and cash flow: US evidence. Int. J. Account. 1993, 28, 140-146.

51. Bag, B.-H.; Bao, D.-H. The time series behavior and predictive-ability results of annual value added data. J. Bus. Financ. Account. 1996, 23, 449-460. [CrossRef]

52. Burchell, S.; Clubb, C.; Hopwood, A.G. Accounting in its social context: Towards a history of value added in the United Kingdom. Account. Organ. Soc. 1985, 10, 381-413. [CrossRef]

53. Shaoul, J. Critical financial analysis and accounting for stakeholders. Crit. Perspect. Account. 1998, 9, 235-249. [CrossRef]

54. Brooks, C.; Oikonomou, I. The effects of environmental, social and governance disclosures and performance on firm value: A review of the literature in accounting and finance. Br. Account. Rev. 2018, 50, 1-15. [CrossRef]

55. Seiford, L.M.; Thrall, R.M. Recent developments in DEA. J. Econom. 1990, 46, 7-38. [CrossRef]

56. Belu, C. Ranking corporations based on sustainable and socially responsible practices. A Data Envelopment Analysis (DEA) Approach. Sustain. Dev. 2009, 17, 257-268. [CrossRef]

57. Lo, S.-F. Performance evaluation for sustainable business: A profitability and marketability framework. Corp. Soc. Responsib. Environ. Manag. 2010, 17, 311-319. [CrossRef]

58. Curtis, P.; Hanias, M.; Kourtis, E.; Kourtis, M. Data envelopment analysis (DEA) and financial ratios: A pro-stakeholders' view of performance measurement for sustainable value creation of the wind energy. Int. J. Econ. Bus. Adm. 2020, 8, 326-350. [CrossRef]

59. Lieberman, M.B.; Balasubramanian, N. Measuring Value Creation and Its Distribution among Stakeholders of the Firm; Social Science Research Network: Rochester, NY, USA, 2007.

60. Sozialbilanz-Praxis. Sozial-Bilanz Heute. Der Betrieb. 1978, 24, 1141-1144.

61. Gruppo di Studio per il Bilancio Sociale. Principi Di Redazione Del Bilancio Sociale; Gruppo di Studio per il Bilancio Sociale: Milano, Italy, 2013. 